第27回年次大会予稿

花粉症と他のアレルギ一疾患に関する医学·生物学の知識を RDFデータとセマンティックWeb技術を用いて一般者に提供する 情報リソース

一 その現状と課題 —

\title{
Information resources of knowledge in medical science and biology about pollinosis and other allergic diseases for people using RDF data and semantic Web technology - Current status and challenges -
}

\author{
ソロビヨワ イェレナ ${ }^{1}$, 石塚 英弘 ${ }^{2 *}$ \\ Elena SOLOVIEVA ${ }^{1}$, Hidehiro ISHIZUKA ${ }^{2 *}$
}

1 情報知識学会正会員, 博士(情報学) 筑波大学, ロシアでは小児科医師

2 筑波大学名誉教授

干 305-0821 茨城県つくば市春日1-2 筑波大学 春日地区 庶務課 気付

E-mail: ishizuka.hidehiro.gm@u.tsukuba.ac.jp

*連絡先著者 Corresponding Author

アレルギー疾患の患者と家族の向上を支援する目的で、本著者は、アレルギー全般に関する情 報と知識を得られるアプリケーションを、セマンティックWeb技術を用いて開発し、2008・2009年に論 文として発表した。日本では、2014年にアレルギー疾患対策基本法が成立して公布され、医師だけ でなく、一般者もアレルギー疾患に関する知識を知る必要があるとされた。しかし、患者と家族のため のアレルギー関連のRDFベースの情報リソースはほとんど見当たらない。そこで、生物医学研究者と 臨床医師を対象として、アレルギー関連の情報を記載している無料で利用可能なオントロジーとデ 一タ・リポジリリの調査を行い、現状を把握した上で、課題を考えた。その結果、本論文では、一般者 のヘルスリテラシーの向上を支援する情報提供システムの実装のために、セマンティックWeb技術の 適用性、セマンティックWeb技術の中でOWLとSKOSの組み合わせの適用性、一般者向けのグラフィ カルユーザインタフェースの必要性などの課題について検討する。 
キーワード: アレルギー疾患, ヘルスリテラシー, セマンテイックWeb, オントロジー, RDF, OWL, SKOS

\section{1 はじめに}

\section{1 アレルギ一疾患とヘルスリテラシー}

アレルギー疾患の場合、治療は医療者が 行うが、疾患の予防、軽減は患者と家族に よる寄与が必要となる。そのため、患者と 家族のヘルスリテラシーの向上が期待さ れる。

ヘルスリテラシー (health literacy) は、米 国の保健福祉省と NIH(National Institute of Health)が 2000 年に発表した定義：”The degree to which individuals have the capacity to obtain, process and understand basic health information and services needed to make appropriate health decisions.”[1] が有名であ る。これを日本語に訳せば「個人が健康上 の課題に対して適切に意思決定するため に必要となる健康に関する基本的な情報 やサービスを獲得、整理、理解する能力の 程度」となる。2000年に保健福祉省が健康 政策の指標として”Healthy People 2010”も 出版し、 health literacyの有用性を示したた め、health literacyは米国市民に広まった。

米国の状況を知った本論文の著者：ソロ ビヨワは「特にアレルギー疾患の場合、患 者と家族はヘルスリテラシーが必要。医師 でない一般者がアレルギー疾患に関する 情報と知識を得られるWebシステムの開発 研究を私は行う。」と決意し、その成果を 2008～2010年に論文 [2], [3]，[4]として発 表した。

ソロビヨワは、この研究を開始する前の 文献調査に基づいて、ヘルシーリテラシー について、次に示寸認識を持っていた。

・欧米では一般市民のヘルスリテラシーの 必要性が指摘されている。ヘルスリテラ
シーが注目されている理由は、医師が患 者に対する医療を決定していた時代か らinformed consentを経て、近年では、患 者・家族と医師が情報と意志を交換し、 お互いの知識、背景を基に患者にとって 最良の医療を選択するSDM（shared decision making）へと変化しているため である。

・医師による説明を患者が理解するには、 ヘルスリテラシーの中の conceptual knowledge が重要とされている。従って、 開発するWebシステムでは、ontology技術 を使用して知識を表現する。

日本のヘルスリテラシーについては、厚 生労働省が2015年に発表した「保健医療 2035」[5]の中で、「子どもから高齢者に至 る生涯を通じた予防・健康づくりを、社会 を挙げて支える必要がある。このため、保 育・幼児教育から職場やコミュニティ等の あらゆる場で、世代を超えた健康に関する 教育の機会を提供し、ヘルスリテラシーを 身につけるための取組みを促進する」と方 針を示した。

ヘルスリテラシーに関する江ロによる 総説 [6]（2018年出版）では、（1）近年、「へ ルスリテラシー」が医療や保健、教育等の 分野で注目されている。（2）世界的にヘル スリテラシーに関する研究が飛躍的に増 加。(3) 厚生労働省の「保健医療2035」が用 語「ヘルスリテラシー」を紹介。(4)しかし、 ヘルスリテラシーの理解者はまだ決して 十分とは言えない。と述べている。

\section{2 アレルギ一疾患の急増とその対策}

ライフスタイルや生活環境の変化に伴 
い、20世紀後半からアレルギー疾患は世界 的に急増しており、日本の全人口の約 2 人 に1人がアレルギー疾患に罹患しているこ とが報告されている。特に、気管支喘息、 アトピー性皮膚炎、アレルギー性鼻炎、ア レルギー性結膜炎、花粉症、食物アレルギ 一の患者が多数存在している。アレルギー 疾患は生活環境での様々な要因で発生し、 生活に多大な影響を及ぼしていることか ら、アレルギー疾患対策を総合的に推進す るために、アレルギー疾患対策基本法が 2014年6月20日に成立した。その法律では、 医療の提供体制を整備するとともに、患者 が科学的知見にもとづく適切な情報を入 手できるよう環境を整備することを求め ている [7]。その法律にもとづいて、2016年 に厚生労働省が基本指針を発表した。

厚生労働省が2015年に発表した「保健医 療2035」[5]の中では、「子どもから高齢者 に至る生涯を通じた予防・健康づくりを、 社会を挙げて支える必要がある。このため、 保育・幼児教育から職場やコミュニティ等 のあらゆる場で、世代を超えた健康に関す る教育の機会を提供し、ヘルスリテラシー を身につけるための取組みを促進するこ とを目的としている。」と述べている。

現在、アレルギー関連の医療関係者向け のコンテンツと一般者向けのコンテンツ が数多く存在している。例えば、一般社団 法人日本アレルギー学会のホームページ には、医学生・若手医師向けと一般の皆様 向けのコンテンツがあり、「一般の皆様へ」 のページ[8]には、「アレルギーを知ろう」、

「アレルギーの病気のQ\&A」、「専門医と は?」などの情報が記載されている。茨城 県庁のホームページには、「アレルギー疾 患対策」というコンテンツ [9]があり、「花
粉症集」には、「総論」、「花粉症の予防」、 「花粉症の症状がでたら」などの花粉症に ついての情報が記載されている。また、環 境省の「花粉情報サイト」 $[10]$ には、花粉 症に関する情報が提供されている。花粉症 対策として、環境省で実施されている花粉 飛散量の予測及び観測、関連する調查研究 等の報告書が記載されている。環境省が作 成した花粉症環境保健マニュアルも公表 している $[11]$ 。“花粉症に関する新しい知 見や関連情報を紹介する”ために作られた そのマニュアルには、「花粉について」、 「花粉症とは」、「花粉症を防ぐためには」 などの情報が記載されている。現状では、 インターネット上で公開されているアレ ルギー関連のコンテンツのほとんどは、 HTMLかPDFの形式で作成されている。

その一方で、生物医学分野におけるセマ ンティックWeb技術の利用が進展しており、 データベースなどの情報リソースの RDF (Resource Description Framework) 化、知 識の記述に用いるオントロジーの作成な どが進められている。本著者は以前の研究 で、アレルギー関連知識を表現するために セマンティックWeb技術を用いて、オント ロジーを構築し、2008年に論文 [2]として 発表した。その時点でのアレルギー関連シ ステム（欧米のシステムと日本のシステム を含む）の利点と問題点も検討した。

その研究から10年が経ち、本発表の元に なった調査では、花粉症に関する医学・生 物学の知識を提供しているRDFべースのオ ントロジーとデータ・リポジトリの現状と 課題の検討を行った。本論文では、一般者 を対象とする情報リソースだけではなく、 生物医学研究者と臨床医師を対象とした 情報リソースのデータの範囲・利用目的・ 
使われている技術・インタフェースなどを 比較しながら、アレルギーに関する情報の 提供における最近の進歩について検討す る.

\section{2 アレルギー学分野における研究}

\section{の方向性}

ソロビヨワらは以前の研究論文 [2]で、ア レルギー学分野での研究の範囲と課題を、 次のとおり記述した。

- アレルギー性疾患の世界的な増加

- アレルギー性疾患の発生に関連するリ スク要因

・アレルギー性疾患の発生に影響を及ぼ す環境と生活習慣の要因

- アレルギー性疾患の予防に関する要因

- アレルギー疾患が生活の質 $(\mathrm{QOL})$ に与 える影響

アレルギー疾患に影響を及ぼす要因：

- 遺伝的要因

- 環境要因

- 社会経済的要因

- 個人の生活習慣の要因

今回の調査で学術文献を検討した結果、 近年のアレルギー学分野で注目を集めて いる研究の対象と課題については以下の ように考える。

- アトピー性疾患における疾患特異的遺 伝的リスク要因と共通の遺伝的リスク 要因の確定

- アトピー性疾患における分子レベルで の要因の確定

- アトピー性疾患（アレルギー感作）に 関与する遺伝的変異の推定

- 遺伝的変異とアトピー性疾患との関連 の分子メカニズムを理解するための統 合分析
それらの研究のために次に示す方法が用 いられている。

$\diamond$ Genome-Wide Association Studies (GWAS) and meta- analysis of GWAS data

$\diamond \quad$ Case-control association study

$\diamond$ Multi-omics analysis

また、次のような目的の研究も行われて いる。

- アトピー性疾患の病因に関与する遺伝 的要因 ${ }^{*}$ 社会的環境因子**の相互作用 の推定

- アトピー性疾患に関する人種や民族な どの遺伝的背景の推定

*アトピー素因 : 家族歴・既往歴（気管 支喘息、アレルギー性鼻炎・結膜炎、 アトピー性皮膚炎のうちいずれか、あ るいは複数の疾患）;免疫グロブリン

E（IgE）が高值

***社会的環境因子 : 環境要因、社会経済 的要因、生活習慣要因

上記の研究で得られたデータは、データ リポジトリなどの情報リソースに掲載さ れ、公開され、他の研究、医療などで利用 されている。その科学的なデータを一般者 に提供することはあまりないが、研究成果 に基づいてアレルギー関連分野における 知識が進歩しているため、その進歩につれ て、一般者にも正確な知識を普及させるこ とは大いに重要と考えられる。

\section{3 花粉症に関する医学·生物学の 知識を提供しているRDFベ一スのオ ントロジーと データ リポジトリの現 状と課題}

3.1 生物医学研究者亡臨床医師を対象之 
した情報リソースのデータの利用目的 - 範 囲·使用されている技術·インターフェース に関する概要

現在は、世界中で生物医学関連の多種多 様なデータベースとデータリポジトリ が公開されている。その中には、アレルギ 一関連の情報も含む情報リソースが数多 く存在している。生物医学研究者と臨床医 師がアレルギー関連の情報リソースを利 用する目的は次に示すように多種多様で ある。

- アレルギー性疾患などの複合遺伝性疾 患*の分子メカニズムを解明するため の解析

- 予測された遺伝子型と疾患の関連性の 生物学的な検証

- 治療の効果の予測と潜在的な副作用の 予測

- 遺伝子と環境との相互作用**の解析

-アアレルギーの有病率と関連するリスク 要因における人種/民族差の解析

- 個別化医療

々 疾患の調節における遺伝的変異と 分子の表現型の役割

々 遺伝子と環境との相互作用の個人 差

$\diamond$ 薬物応答性の個人差

* 複数の遺伝要因と複数の環境要因の影響 による疾患を複合遺伝性疾患と言う。

**遺伝的要因と環境要因の両方が組み合わ さって表現型や疾患の発症につながる。

アレルギー疾患に関する情報リソース は多種多様で膨大なため、アレルギー疾患 の代表の一つであり、患者の数が年々増え ている花粉症を選んで具体的な事例を調 査した。その際に、Amaral et al.[12]の論文
を参考にして、花粉症の発症に関与する複 数の遺伝子の中の一つの遺伝子 (C110RF30, EMSY) を選んだ。その遺伝子の遺伝子座 (C11ORF30) と SNP(single nucleotide polymorphism）（rs2155219）も検索キーワー ドとして選択した。それらの検索キーワー ドに該当するコンテンツを検出した。その 結果は次に示すとおりである。

多様なタイプのデータが RDF で記述さ れ、公開されている。特に、分子生物学の 実験で得られたデータが多い。アメリカの NCBI (National Center for Biotechnology Information) も含めて、国内外の研究機関な どで情報リソースの RDF 化が行われている が、The European Bioinformatics Institute (EMBL-EBI) で開発されたデータベースや データリポジトリなどの情報リソースの RDF 化が特に進んでいる。

殁どの場合、セマンティック Web 技術と して使われているのはRDFと Web Ontology Language (OWL)であり、オントロジー等の 開発のために Simple Knowledge Organization System (SKOS) が使用されて いる事例は少ない。そのうちの一つは、

Ontotext 社で開発されている Linked Life Data (LLD) [13] のプラットフォーム (http://linkedlifedata.com/sources.html)である。 インターフェースでは、RDF filesのダ ウンロード、SPARQL Endpoint の提供など 様々なインターフェースが用意されてい るが、グラフィカルユーザインターフェー スが用意されている事例は少ない。

\section{2 一般者を対象とする情報リソースの 現状と課題}

現状としては、3.1節で述べたように、一 般者向けのアレルギーを対象とした専用 の情報リソースが数多く存在している。し 
かし、ほとんどの場合、データの形式は HTMLであり、RDFベースのコンテンツは国 内外に見当たらない。

アレルギーの概念を扱うオントロジーに 関しては、前節で述べたような科学的なデ 一タを記述するために使われているオン トロジー以外に、アレルギーに関連する概 念を含む、多様なトピックを統合的に対象 とするオントロジーもある。そのようなオ ントロジー等は、国民に情報を提供する上 で重要な役割を果たしているそれぞれの 国の国立図書館のサービスのためにも使 用されている。アメリカ合衆国の国立図書 館と欧州のいくつかの国の国立図書館で 開発された Subject Headings、Thesauruses、 Ontologiesなどがある。その例を下記に示す。

$>$ ID.LOC.GOV - Linked Data Service; Library of Congress Subject Headings (LCSH); Publisher: The Library of Congress (SKOS/RDF)

\section{$\diamond$ Allergy:}

http://id.loc.gov/authorities/subjects/s $\underline{\mathrm{h} 85003662 . \mathrm{html}}$ (Instance of SKOS Concept)

$\diamond$ Hay fever:

http://id.loc.gov/authorities/subjects/s h85059408.html (Instance of SKOS Concept)

$>$ The National Agricultural Library's Agricultural Thesaurus; Publisher: National Agricultural Library (Download in RDF-SKOS)

$\diamond \quad \mathrm{H}$ Health and Pathology, hay fever: https://agclass.nal.usda.gov/mtwdk.e $\underline{\mathrm{xe}} \mathrm{k}=\mathrm{default} \& \mathrm{l}=60 \& \mathrm{n}=1 \& \mathrm{~s}=5 \& \mathrm{t}=2$ $\underline{\mathrm{w}=199143}$
$>$ General Finnish Ontology (YSO);

Publisher: National Library of Finland $\diamond$ allergy: https://finto.fi/yso/en/page/p342 (Download in RDF/XML, SKOS) $\diamond$ pollinosis: https://finto.fi/yso/en/page/p27671 (Download in RDF/XML, SKOS)

The data.bnf.fr project; Publisher: French National Library (BnF)

$\diamond$ Médecine, Allergie: https://data.bnf.fr/11930868/allergie/ (Download in RDF/XML, SKOS)

$>$ Catalogue of the German National Library; Publisher: The German National Library $\diamond$ Allergy:

https://portal.dnb.de/opac.htm?metho $\underline{\mathrm{d}=\text { simpleSearch\&cqlMode }=\text { true \&qu }}$ ery $=$ nid\%3D4001257-8 $\quad$ (Download in $\mathrm{RDF} /$ Turtle)

上記の図書館では、多様な概念がオント ロジーの形で記述され、「Documents on this topic」などのプロパティーの使用で、それ らの図書館の情報リソースのトピックが 明確に記述されており、ユーザーのニーズ に合わせて探しやすい形で情報リソース が提供されている。例を挙げると、The German National Library[14]では「The Subject Headings Authority File」も含めて $\lceil$ The Integrated Authority File (GND)」が作 成されており、ライセンスに基づいて無料 で、様々な方法でユーザーが利用可能とな っている。たとえば、RDF/XML formatで Linked Data Serviceに提供されている。GND のデータは、カタログ化を単純化し、明確 な検索アクセスポイントと、異なる情報リ ソース間のリンクを提供する。 


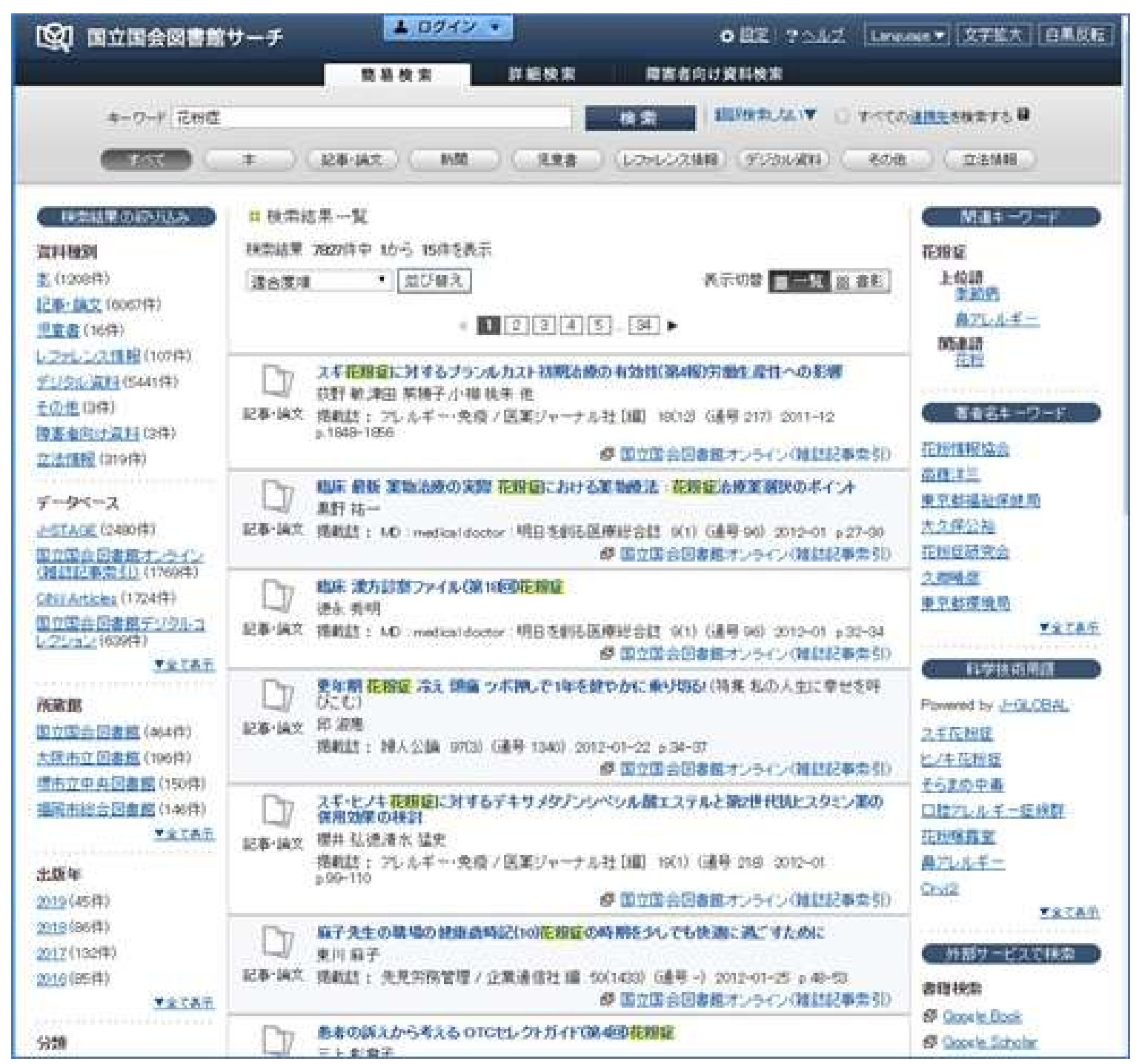

図1 国立国会図書館サーチ [15]を用いた「花粉症」の文献の検索

検索結果は花粉症の関連語群(上位語、関連語)を用いて判定した適合度順に表示

日本の国立国会図書館のサーチサービ スなどでも、RDF/XMLベースのダブリンコ アメタデータが作成され、それらのメタデ 一タの使用で、それぞれのトピックに関す る多様な情報が、構造化された分かりやす い形で提供されている。花粉症のキーワー ドで行った検索の結果を図1に示す[15]。

各図書館で独自開発されたオントロジ 一が利用されるだけではなく、“Exactly Matching Concepts" 、Closely Matching
Concepts from Other Schemes" "Narrower Concepts from Other Schemes”などの $\mathrm{RDF} / \mathrm{SKOS}$ のプロパティーによって、オント ロジーが互いにつながっているため、他の 図書館の情報リソースも效率的に利用で きるようになっている。

3.1節で述べたように、生物医学データ を記述するために開発されたオントロジ 一の実装はほとんどがOWLべースのもので あり、OWLとSKOSの組み合わせ（SKOS in 
combination with OWL) で実装されたオント ロジーの事例（Linked Life Data [13o16] (http://linkedlifedata.com/sources.html））は 少ない。

その一方で、図書館の情報資源を記述す るために開発されたオントロジーの実装 に、SKOS が広く利用されている。なぜなら、 SKOS は thesauri、taxonomies、classification scheme、subject heading systems などの knowledge organization systems を構築する ために開発された RDF ベースの技術だから である。また SKOS は、知識ベースなどの複 雑なタイプのオントロジーの実装にも適 している。

ソロビヨワらは糖鎖代謝異常症に関す るオントロジー論文[16]の中で、 [SKOS in combination with OWL]の利点について検討 し、SKOS の重要な機能と利点とし て、 "concept scheme" の 概 念 と "skos:closeMatch” と “skos:exactMatch" などの SKOS mapping properties を挙げて、 次のように述べている。

• “SKOS concept scheme”の概念は、2 つ以 上の異なる “knowledge organization systems”を扱うときに役立つ。

• “SKOS mapping properties” は、異なるス キームからの 2 つの概念が同等の意味を 持つことを示し、これらの意味を指定す るときに役立つ。このアプローチは、さ まざまな情報リソースの統合を通じて 発生する可能性がある分類上の競合を 回避するのに役立つ。

以上の観点から、一般者にアレルギー疾患 に関する情報を提供するためには、セマン ティック Web 技術が未だ十分活用されて いない点に問題があると考える。

\section{3 アレルギーに関する情報の提供にお}

\section{ける新しい取り組み}

新しいサービスの提供のため、新たなア プローチを提案する研究が進んでいる。以 下に、2つの研究事例を示す。

\subsection{1 天気やユーザーの健康状態に応じ た料理のレシピを提案するシステム}

Gyrard et al. [17］の論文には、次のよう に書かれている。Machineto-Machine (M2M) standardにより、人手を介さずにセンサーな どのマシンとデバイスが互いに通信可能 になる。M2Mデバイスは大量のM2Mデータを 提供し、天気予報、ヘルスケアなどの特定 のM2Mアプリケーションに使用される。

大きな課題は、これらの異種ドメインに よって提供されたM2Mデータを組み合わせ ることである。論文の著者らは、有望なク ロスドメインのM2Mアプリケーションを提 供するためにsemantic-based approachを実 行した。具体的には、M2Mデータを自動的に 組み合わせるためにセマンティックWebテ クノロジを使用した。そのアプローチを検 証するために、クロスドメインのM $2 M$ デー 夕を組み合わせて、天気やユーザーの健康 状態に応じたレシピを提案するシステム を実現した。

システムには、アレルギー関連の情報も 含まれ、“Milk contains lactose?”や“Allergic to lactose?”の質問に答えるためにHealth ontologyも使用されている。

このような研究が進めば、専門知識を持 たない一般者もアレルギーに関する情報 の取得が簡単になることが期待される。

\section{3 .2 自然言語質問文からSPARQLクエリ を自動生成する手法の提案}

現在、RDF で記述された情報リソースか ら必要な情報を取得するために広く使わ れている方法は、SPARQL クエリ言語で問い 
合わせする方法である。その方法を用いる には、SPARQL に関する知識が必要になる。 そこで、SPARQL 文ではなく、自然言語で与 えられた質問文を SPARQL クエリに変換し て、知識への問い合わせを可能にする研究 も進んでいる。日本では、DBCLS をはじめ として、研究機関と大学などで、RDF 形式 の情報の処理を支援する自然言語の応用 に関する研究が行われ、その中に、アレル ギーに関する情報を対象とした研究もあ る。

例えば、村山友理 et al. の論文[18]で は、自然言語質問文から SPARQL クエリを 自動生成する手法が提案され、提案手法の 有効性を検証するためにアレルギー関連 の質問「カルボナーラはどんなアレルギー 食材を含みますか?」と「どんなアレルギ 一食材がカルボナーラに含まれますか?」 に適用され、成功した。

RDF によって表現された知識への問い合 わせを自然言語文で行う方法が普及すれ ば、アレルギーに関する多種多様な情報が 簡単に得られるようになる。

\section{4 結論}

既に公開されているアレルギー関連の $\mathrm{RDF}$ ベースの情報リソースについて、今回 調査を行った。その結果、現状と課題に関 する結論として、以下のことが言える。

$\mathrm{RDF}$ ベースの情報リソースの対象者に 関しては、生物医学研究者と臨床医師を対 象とした情報リソースが多く存在するに も拘らず、一般者を対象とした RDF ベー スの情報リソースは少なく、不十分である。 利用目的に関しては、研究目的の方が多 い。患者とその家族、一般者のヘルスリテ ラシーの向上を支援するための情報リソ
ースは未だ未だ少ない。この問題を解決す るには、情報の概念を明確に表現できるこ とや多様なトピックの情報を統合化でき ることなど、多くの利点を持つセマンティ ック Web 技術を用いて、一般者向けに情報 を提供する情報リソースを作成すること が有効である。データの RDF 化とオント ロジーの使用で、患者とその家族に役に立 つ豊かな内容のコンテンツを提供できる と考えられるからである。

データの範囲に関しては、分子レベルの データが数多く存在している。しかし、 RDF 形式での臨床データ (Clinical data)、 薬に関連するデータ（Drug related data）、環 境データ（Environmental data）などのデー タは少ない。そのデータの $\mathrm{RDF}$ 化が重要 である。

オントロジーに関しては、 3.1 節と 3.2 節 で述べたように、アレルギー関連のコンセ プトが多様なオントロジー（Experimental Factor Ontology (EFO)、Human Phenotype Ontology (HPO)、Monarch Disease Ontology、 Mesh など）に入っているが、アレルギーを 対象とした専用のオントロジーがまだ存 在していない。その意味で、ソロビヨワら が以前の研究[2]で開発したオントロジー のようなアレルギー関連のオントロジー のニーズがあると考えている。

インターフェースに関しては、RDF files のダウンロード、SPARQL Endpoint の提供 などの開発者向けのインターフェースが 多いが、interactive user interface based on SPARQL queries などのグラフィカルユー ザインターフェース (GUI)は少ない。研究者 と臨床医師向けに情報提供を行う場合に も GUI が重要であるが、一般人向けに情報 提供システムを構築する場合は、GUI の開 
発が必須である。

1.2 節の中でアレルギー関連の情報リソ ースとして挙げた日本アレルギー学会、茨 城県庁と環境省で作成されたコンテンツ は、それぞれの独自のリソースであり、ユ ーザーがそれらの情報を見るために八イ パーリンクか検索エンジンを使用し、それ ぞれのサイトに行って閲覧する必要があ る。しかし、それらの情報を RDF 形式で記 述し、その上、関連オントロジーを用いる ことで、異なった機関によって作成された コンテンツ、更に異なったタイプの情報を 対象にしたコンテンツの間で、アプリケー ションレベルでの連携と統合が可能にな る。また、3.3.1 節や 3.3.2 節で紹介した 手法も有効かと思われる。情報リソースに 関する新しい技術が新たな道を切り開い てきた歴史がある。今後の展開・進展に期 待したい。

\section{謝辞}

本研究の元になった調査は著者である ソロビヨワが JST : 国立研究開発法人 科学 技術振興機構 NBDC : バイオサイエンスデ ータベースセンターに勤務していた時に 実施した調査であり、その機会を頂いた JST（NBDC）に深く感謝する.

\section{参考文献}

[1] Health Literacy, Clear Communication, https://www.nih.gov/institutes-nih/nih-officedirector/office-communications-publicliaison/clear-communication/health-literacy （2019年4月 10 日参照）

[2] E. Solovieva; H. Ishizuka:“An application of the Semantic Web technologies in the knowledge domain related to the allergy",
Journal of Japan Society of Information and Knowledge (情報知識学会誌), Vol.18, No. 1, pp. 22-46, 2008.

[3] ソロビヨワイェレナ; 石塚英弘：「ア レルギー性疾患に関する一般者向けの基 本情報を提供するWebシステムの設計と開 発」, Health Sciences (日本健康科学学会誌), Vol. 25, No. 4, pp. 235-48, 2009.

[4] E. Solvieva：「アレルギー関連知識の構 造化及びオントロジー構築に基づく情報 提供システムの研究」, 博士論文, 2010 . https://ci.nii.ac.jp/naid/500000530025 （2019 年4月 10 日参照)

［5］厚生労働省：「保健医療 2035」,

https://www.mhlw.go.jp/file/04-

Houdouhappyou-12601000-

Seisakutoukatsukan-

Sanjikanshitsu_Shakaihoshoutantou/00000886 47.pdf (2019年4月 10 日参照)

６］江口 泰正：「健康教育の新しいキーワ ードとしてのヘルスリテラシー」, Journal of The Japan Dietetic Association, Vol.61, No.10, pp.557-565, 2018.

[7］一般社団法人 日本アレルギー学会 : アレルギー疾患対策基本法，「アレルギー 疾患対策基本法とはどういう法律なのか」， https://www.jsaweb.jp/modules/law/index.php ?content $\mathrm{id}=1$ （2019年4月 10 日参照）

[8］一般社団法人 日本アレルギー学会 : 一般の皆様向けコンテンツ，「一般の皆様 へ」, https://www.jsa-pr.jp/（2019年4月10日 参照)

[9] 茨城県庁：アレルギ一疾患対策, 「花粉症について」, https://www.pref.ibaraki.jp/hokenfukushi/yobo /shitpei/yobo/kafun/kafun-joho-top.html (2019年4月 10 日参照) 
[10］環境省：保健・化学物質対策，「花 粉情報サイト」，

https://www.env.go.jp/chemi/anzen/kafun/ （2019年4月 10 日参照）

［11］環境省：保健 - 化学物質対策, 「花粉 症環境保健マニュアル 2014年1月改訂版」 https://www.env.go.jp/chemi/anzen/kafun/man ual.html（2019年4月10日参照）

[12] A.F. Amaral; C. Minelli; S. Guerra; et al.: "The locus C11orf30 increases susceptibility to poly-sensitization", Allergy, Vol.70, No.3, pp. 328-333, 2015.

[13] Linked Life Data : Sources, Repository overview

http://linkedlifedata.com/sources.html (2019 年 4 月 11 日参照)

[14] The German National Library : Integrated Authority File (GND)

https://www.dnb.de/EN/Standardisierung/GN

D/gnd node.html (2019 年 4 月 10 日参照)

[15］日本の国立国会図書館のサーチサー ビス, 花粉症のキーワードで行った検索
の結果

https://iss.ndl.go.jp/books?ar=4e1f\&any=\%E8 \%8A\%B1\%E7\%B2\%89\%E7\%97\%87\&op id $=1$ (2019 年 4 月 10 日参照)

[16] E. Solovieva; T Shikanai; N Fujita; H. Narimatsu: "GGDonto ontology as a knowledge-base for genetic diseases and disorders of glycan metabolism and their causative genes", J. Biomedical Semantics, Vol.9, No.14, 2018.

[17] A. Gyrard; C. Bonnet; K. Boudaoud: "Enrich Machine-to-Machine Data with Semantic Web Technologies for Cross-Domain Applications", 2014 IEEE World Forum on Internet of Things (WF-IoT), DOI: 10.1109/WF-IoT.2014.6803229.

［18］村山友理 ; 小林一郎; 森田武史 ; 中野 有紀子; 山口高平：「自然言語の SPARQL ク エリ変換に基づく大規模知識へのアクセ ス手法の基礎的検討」, 言語処理学会 第 24 回年次大会 発表論文集 (2018 年 3 月). 